TOMASZ PRUSIŃSKI ${ }^{1}$

Zakład Psychologii Osobowości

Studia Psychologica

UKSW

Instytut Psychologii

17(1) 2017 s. $23-46$

Akademia Pedagogiki Specjalnej w Warszawie

DOI:10.21697/sp.2017.17.1.02

\title{
Z BADAŃ NAD PRZYJAŹNIĄ. KOMPETENCJE SPOŁECZNE A JAKOŚĆ RELACJI PRZYJACIELSKICH
}

\section{STRESZCZENIE}

Przyjaźń jest uniwersalną relacją między ludźmi, ważną w kontekście życia społecznego i zdrowia psychicznego jednostki. Dotychczasowe badania empiryczne i rozważania teoretyczne wskazują, że kompetencje społeczne są związane z przyjaźnią. Badania empiryczne prezentowane w tym artykule koncentrują się na odnalezieniu i opisaniu związków między kompetencjami społecznymi a jakością relacji przyjacielskich wśród młodych dorosłych. Wyniki badań wskazują, że jednostki, które mają rozwinięte pewne umiejętności społeczne, mają również wysokiej jakości relacje przyjacielskie.

Słowa kluczowe: przyjaźń, kompetencje społeczne

FROM RESEARCH ON FRIENDSHIP.

SOCIAL COMPETENCIES AND THE QUALITY OF FRIENDSHIP RELATIONS

\section{ABSTRACT}

Friendship is a universal interpersonal relationship and is important in an individual's social life or mental health. Previous empirical studies and theoretical considerations suggests that social competencies are correlated with friendship. The study focuses on finding and describing correlations between social competencies and the quality of friendship relations among young adults. Results of the empirical research allow to derive some important conclusions. Studies have assessed that individuals which are socially competent in a some dimension have the high quality of friendship relations.

Keywords: friendship, social competencies

\section{Wartość relacji przyjacielskich}

Ludzie są istotami społecznymi i to właśnie w relacjach z innymi ludźmi znajdują zaspokojenie wielu swoich potrzeb. Jakość bliskich relacji interpersonalnych, które człowiek konstruuje w kontakcie z innymi, zwłaszcza przyjaźni, jest zasadniczym czynnikiem jego zdrowia psychicznego (Ikporukpo, 2015). Z wieloma niepowodzeniami związanymi z naturalnym cyklem życiowym człowieka czy

1 Adres do korespondencji: tomasz.prusinski@op.pl. 
też z trudnościami nieprzewidywalnymi może on sobie doskonale poradzić, jeśli w swoim otoczeniu społecznym ma przyjaciół. Dobrostan psychiczny, satysfakcja z pracy zależą w zasadniczym stopniu od jakości przyjaźni (Ryff, Singer, 2001). Badania empiryczne pokazują, że ludzie bardziej cenią sobie dobre przyjaźnie i związki romantyczne niż bezpieczeństwo finansowe. Obecność drugiego człowieka w życiu jednostki nadaje mu sens i wyznacza horyzont funkcjonowania. Relacje przyjacielskie wobec współczesnego procesu erozji wartości rodziny stają się również jednym z niewielu trwałych elementów kapitału społecznego człowieka.

\section{Trudności w badaniach nad przyjaźnią i propozycja modelu teoretycznego}

W literaturze naukowej istnieje wiele pozycji poświęconych przyjaźni. Jednak większość badań empirycznych i interesujących analiz teoretycznych pochodzi $\mathrm{z}$ ośrodków naukowych zlokalizowanych poza starym kontynentem. Polskie czasopisma psychologiczne w ostatniej dekadzie publikują niewiele artykułów poświęconych temu zagadnieniu (McAndrew, Rybak, 2006; Szarota, 2014; Szarota, Cantarero, Matsumoto, 2015; Szczepańska, Gaweł-Luty, 2009). Niektóre aspekty przyjaźni ukazywane $\mathrm{w}$ dostępnych opracowaniach nie wydają się podbudowane solidnymi badaniami empirycznymi (Szczepańska, Gaweł-Luty, 2009), bazują na niewielkich próbach badawczych (McAndrew, Rybak, 2006) lub mają charakter teoretyczno-metodologiczny i zawierają tylko pewne wątki empiryczne - doniesienia z badań zagranicznych (Szarota, 2014). Istnieją opracowania z połowy lat 90. (Prężyna, 1996), jednak dotyczą one problematyki atrakcyjności interpersonalnej i z racji chociażby przemian kulturowych w naszym kraju (Marody, Giza-Poleszczuk, 2004) wymagają uzupełnienia bieżącym obrazem relacji przyjacielskich. Wydaje się, że polski psycholog nie dysponuje szeroką, a zwłaszcza bieżącą wiedzą na temat relacji przyjacielskich istniejących w polskim społeczeństwie. Nadal nie ma też zgody w zakresie definicji zjawiska. Psychologia jak dotąd nie poradziła sobie w pełni z definicją przyjaźni, a proces operacjonalizacji napotyka na pojęcie wieloznaczne, które w części pokrywa się znaczeniowo $\mathrm{z}$ innymi pojęciami.

Adams, Blieszner i de Vries (2000), prowadząc własne badania dotyczące relacji przyjacielskich, prosili ludzi o identyfikowanie kryteriów, które są najbardziej istotne dla uchwycenia definicji ich własnych przyjaźni. Analiza wskazała ponad 20 takich czynników.

Szarota (2014) podkreśla, że korzystając z dotychczas istniejących definicji przyjaźni, nieuchronnie myli się relacje przyjacielskie z innymi bliskimi relacjami. Stąd też należy podkreślić w tym momencie fakt, że istnieją bardziej i mniej udane próby definiowania tej specyficznej więzi interpersonalnej.

Badacze społeczni opierają się często na definicji Argyle’a (1999), który podkreśla komponentę zaufania, wsparcia i lubienia oraz istnienie równorzędności osób w tej relacji. Z kolei propozycja definicyjna Adelmana, Parksa 
i Albrechta (2000) za zasadnicze wymiary przyjaźni podaje dobrowolność, pomoc i równość pozycji. Istotna jest zwłaszcza ta pierwsza komponenta, ponieważ przyjaźń od relacji rodzinnych czy pracowniczych odróżnia wybór, a nie obowiązek.

Na uwagę zasługują również kryteria przyjaźni wskazywane przez rodzimych badaczy: Niebrzydowskiego i Płaszczyńskiego (1989), którzy kompilują wzajemną relację przyjacielską do trzech wymiarów: stopnia, w jakim partnerzy odnoszą się do siebie jako osób autentycznych i zaangażowanych; stopnia, w jakim partnerzy uważają się za osoby wyjątkowe i niedające się zastąpić w bieżącej sytuacji; oraz stopnia dobrowolnej wzajemności, jaka między nimi panuje. W tym ostatnim przypadku chodzi o poziom zgodności tego, jak plany życiowe i działanie jednej strony relacji są podejmowane przez drugą stronę, i jak bardzo osoby utożsamiają się ze sobą.

Jeszcze inną propozycją są style przyjaźni Pahla (2008). Odszedł on od definicji przyjaźni w kierunku rozróżnienia trzech preferowanych sposobów realizowania przyjaźni. Dokonuje rozróżnienia między przyjaźnią opartą na korzyściach, na przyjemności i na charakterze. Pierwszy styl, oparty na korzyściach, wiąże się z lokowaniem danej relacji przyjacielskiej w określonej przestrzeni naszego życia. Pahl mówi tu o przyjaciołach towarzyszach, którzy bywają użyteczni i podobni do nas w bardzo wąskim sektorze naszej aktywności. Z takimi przyjaciółmi chodzi się na zakupy lub wychodzi na piwo. Drugi styl przyjaźni opiera się na dostarczaniu wsparcia i otuchy oraz chroni przed funkcjonowaniem w relacjach zawodowych, opartych przede wszystkim na współzawodnictwie. I w końcu styl trzeci, który Pahl przedstawia jako relację idealną. O ile w poprzednich typach zasadniczo można odkryć powierzchowność i użyteczność relacji, o tyle styl trzeci jest uzupełniony o składnik otwartości i bezinteresowności.

$\mathrm{Na}$ potrzeby badań empirycznych prezentowanych w niniejszym artykule został wybrany określony model teoretyczny opisujący relacje przyjacielskie. Przyjęto go za Davisem (1985) oraz Arunkumarem i Dharmangadanem (2001). Badania w tym modelu teoretycznym były prowadzone również przez McAndrew i Rybak (2006). Relacja przyjacielska jest tu rozumiana jako długotrwała i stanowi jeden $\mathrm{z}$ najbardziej cenionych rodzajów relacji interpersonalnych. Zasadniczą przyczyną deprywacji i samotności człowieka jest właśnie brak relacji przyjacielskich. Ludzie nieuczestniczący w przyjaźni określają otaczający świat jako wrogi (Prusiński, 2016a). Budowanie relacji przyjaźni między dwojgiem ludzi jest wynikiem potrzeby afiliacji, która obejmuje potrzeby obecności i towarzystwa drugiego człowieka oraz rozwijania bliskiej, a z czasem intymnej więzi.

Powyższa propozycja definicyjna relacji przyjacielskiej wskazuje cztery komponenty. Pierwszym wymiarem jest akceptacja tej relacji, możliwość funkcjonowania w relacji przyjacielskiej, której ważnymi wymiarami są również szacunek i uznanie. Akceptacja to przyjmowanie drugiego człowieka takim, jakim on 
jest, bez skłaniania go do modyfikacji zarówno na poziomie zachowania, jak też wartości i postaw. Szacunek zakłada, że druga strona dokonuje dobrych ocen i kieruje się rozsądkiem. Drugim wymiarem jest wzajemne wsparcie w relacji, rozumiane jako wzajemna pomoc (dawana i otrzymywana) w sytuacji przeżywanych problemów i kryzysów oraz osobistych zmartwień. Chodzi tu również o wzajemne poparcie i rzecznictwo, a także wyrażanie swojej opinii. Trzeci wymiar to intymność $\mathrm{w}$ relacji, w sensie dzielenia się osobistymi doświadczeniami i wewnętrznymi przeżyciami. Na poziomie intymności zakłada się również wzajemne zrozumienie jako rozumienie nie tylko pewnych faktów z życia drugiej osoby, lecz także bardziej fundamentalnie - jako rozumienie jej najbardziej osobistych powodów zachowania. Czwarty wymiar to harmony, którą najlepiej będzie tłumaczyć jako zestrojenie w relacji. Arunkumar i Dharmangadan (2001) podkreślają, że w przypadku tego ostatniego wymiaru mówimy o przyjemności z obecności i towarzystwa drugiej osoby, spontaniczności w relacji i w wyrażaniu osobistych postaw, a także o pewnej stabilności relacji.

Model ten, podobnie jak w innych badaniach (Prusiński, 2016b, 2016c), wybrano z dwóch powodów. Po pierwsze, propozycja ta wskazuje na bardzo szeroki wachlarz wymiarów relacji przyjacielskiej, dlatego w podejściu tym można dokonać określenia jakości przyjaźni w sposób szeroki, jeśli nie nawet wyczerpujący. Model wydaje się umożliwiać zebranie w stosunkowo krótkim czasie sporej liczby danych dotyczących różnych aspektów funkcjonowania człowieka w relacji przyjacielskiej. Po drugie, w oparciu o model przyjaźni Davisa (1985) oraz Arunkumara i Dharmangadana (2001) powstało narzędzie pomiarowe skala intensywności relacji przyjacielskich.

\section{Pojęcie kompetencji społecznych}

Dokonując przeglądu literatury dotyczącej drugiego pojęcia kompetencji społecznych istotnego $\mathrm{z}$ uwagi na przedstawiane $\mathrm{w}$ tym artykule badania, można odnieść wrażenie, że jest to jeden z tych terminów występujących w naukach społecznych, który nie jest jednoznacznie definiowany i akceptowany przez wszystkich autorów. Widać to wyraźnie na poziomie przyjętych, a konstytuujących pojęcie kompetencji społecznych, założeń natury teoretycznej i przyjmowanych określeń oraz definicji. Kompetencje społeczne są definiowane jako: efektywność komunikacyjna (Haman, 1992; za: Martowska, 2012), zdolność komunikacyjna (Maxim, Nowicki, 2003), umiejętności komunikacyjne (Wojciszke, Pieńkowski, 1985), a czasami także bardzo enigmatycznie, jako transgresyjny potencjał podmiotu (Chrost, 2012). Zdarza się również i tak, że w obręb definicji kompetencji społecznych włączane są te dyspozycje, które dotychczas traktowano jako zdolności: inteligencja emocjonalna i społeczna (Martowska, 2012).

Pojęcie kompetencji społecznych jest w tym artykule definiowane za Matczak (2007, s. 7). Przyjmuje ona, że są to „złożone umiejętności warunkujące 
efektywność radzenia sobie w określonego typu sytuacjach społecznych, nabywane przez jednostkę w toku treningu społecznego".

Istotne $\mathrm{z}$ uwagi na tematykę niniejszej pracy jest pojęcie sytuacji społecznych. Podstawę ich definiowania przyjmujemy za Matczak (2008) i Martowską (2012), podkreślając jednocześnie fakt, że zdaniem niektórych psychologów (Mika, 1987) sytuację społeczną, przynajmniej w sensie psychologicznym, konstytuuje również relacja: człowiek i jego wytwór. Zdaniem Matczak (2008) sytuacje społeczne to takie, w których mają udział inni ludzie jako partnerzy działania. Martowska (2012) podkreśla, że przez sytuacje społeczne należy rozumieć relacje dwuosobowe przyjacielskie, pracownicze i koleżeńskie, ale również relacje w grupie osób. Można zatem oczekiwać, że efektywność radzenia sobie w sytuacjach społecznych, w tym w utrzymywaniu cennej relacji przyjaźni, powinna zależeć od poziomu rozwiniętych kompetencji społecznych.

Inną ważną kwestią jest to, czy kompetencje społeczne mają charakter ogólny i tym samym ujawniają się w każdej sytuacji społecznej, bez względu na jej rodzaj, czy też mają charakter swoisty. Założenie o specyficznym charakterze kompetencji społecznych wskazuje na to, że różnorodne kompetencje społeczne są wykorzystywane w zróżnicowanych jakościowo relacjach interpersonalnych. Wybór tej, a nie innej kompetencji społecznej zależy od kontekstu społecznej relacji, w jakiej dana jednostka się znalazła.

Matczak (2007) przyjmuje istnienie wielu kompetencji specyficznych. To dzięki określonym kompetencjom społecznym możliwe jest sprawne i efektywne funkcjonowanie w sytuacjach społecznych o odmiennej naturze lub różniących się przynajmniej kontekstem, w którym zachodzą. Określone sytuacje społeczne wymagają od jednostki przyjęcia ról społecznych i towarzyszących im zachowań adekwatnie do istniejących okoliczności. Umiejętność wchodzenia w złożone układy interakcji społecznych, umiejętność ich podtrzymywania oraz stosowania odpowiednio do sytuacji stanowi miarę kompetencji społecznych. Matczak powołuje się tu na Argyle’a (1999), który wskazuje, że różne typy relacji interpersonalnych wymagają różnych umiejętności społecznych. W tej pracy empirycznej została przyjęta właśnie taka optyka kompetencji społecznych, pomimo tego, że są też autorzy, którzy przyjmują, iż istnieje jedna umiejętność ogólna, niemająca charakteru specyficznego, ujawniająca się we wszystkich sytuacjach społecznych, bez względu na ich charakter (Spitzberg, Cupach, 1989).

Kontynuując myśl Argyle’a (1991) o adekwatności różnych kompetencji społecznych wobec różnego typu relacji interpersonalnych, należy podkreślić, że jego zdaniem osoba, która być może radzi sobie doskonale $\mathrm{z}$ sytuacjami ekspozycji społecznej, niekoniecznie musi radzić sobie również w sytuacjach intymnych, oznaczających bliskie kontakty interpersonalne, związane z wysokim poziomem bliskości i zażyłości.

Argyle wymienia dokładnie cztery podstawowe rodzaje sytuacji społecznych, które mogą być bardzo wymagające. Wydaje się, że sytuacje te wymagają 
specyficznej otwartości na partnera i na własne emocje, umiejętności radzenia sobie z konfliktami i problemami oraz sprawnej komunikacji własnych myśli i uczuć. Są to sytuacje: intymne, formalne, wymagające asertywności i sytuacje, kiedy na danej osobie skupiona jest uwaga innych. Tym samym można przypuszczać, że dana jednostka, w zależności od poziomu rozwoju określonych kompetencji społecznych, będzie w powyższych sytuacjach radziła sobie różnie.

Przyjmując definicje tych sytuacji za Matczak (2001), należy uznać, że sytuacje intymne to bliskie kontakty między jednostkami. Cechą charakterystyczną owych kontaktów jest odsłanianie się, zwierzanie i wysłuchiwanie zwierzeń. Ten typ sytuacji może dotyczyć zarówno kontaktów face to face, jak i kontaktów pośrednich. Sytuacje intymne angażują emocjonalnie, są naznaczone bliskością i przywiązaniem. Sytuacje ekspozycji społecznej to takie, w których jednostka jest przypuszczalnie dostrzegana i oceniana przez innych ludzi. W sytuacjach wymagających asertywności jednostka stoi przed podejmowaniem działań kompatybilnych $\mathrm{z}$ własnym interesem, bez niepotrzebnego lęku i bez naruszania praw innych ludzi. Asertywność odnosi się do sytuacji społecznych, w których istnieje ryzyko konfliktu, ale również sytuacji realizacji własnych oraz cudzych potrzeb i oczekiwań.

W definiowaniu kompetencji społecznych przyjmuje się również ich złożoność. Zwłaszcza Argyle $(1991,1999)$ podkreśla ten aspekt zjawiska. Jego zdaniem na kompetencje społeczne składają się różne umiejętności szczegółowe. Wśród wielu można wskazać umiejętność komunikacji niewerbalnej, odraczania gratyfikacji, udzielania wsparcia innej jednostce, umiejętność społecznej syntonii w kontakcie z drugim człowiekiem, odczuwania i rozumienia jego punktu widzenia. Kompetencja społeczna aktywizuje się również w określonym kontekście, o którego rodzaju decydują takie elementy jak: typ relacji, poziom rozwoju relacji i faza zaangażowania, a także charakter zadania, jakie należy wykonać, czy rodzaj celu, jaki jednostka założyła. Jak podkreśla Martowska (2012), właściwością dyskryminacyjną kompetencji społecznej jest sprawczość jednostki, czyli skuteczność w osiąganiu celów.

\section{Kompetencje społeczne a relacje przyjacielskie}

Nawiązywanie, podtrzymywanie i funkcjonowanie w bliskich relacjach przyjacielskich, w które wkomponowane są sytuacje intymne i wymagające asertywności, wymaga określonych kompetencji społecznych, umożliwiających sprawne, umiejętne i, co najważniejsze, efektywne funkcjonowanie. Zdaniem Martowskiej (2012) wydaje się, że w ogóle rdzeniem budowania bliskich relacji interpersonalnych jest wspomniana umiejętność odsłaniania się i zaufanie, które decydują o jakości i głębi zaangażowania w relacji przyjacielskiej. Podobnie ważna $\mathrm{w}$ sytuacji budowania i utrzymywania relacji przyjacielskiej wydaje się umiejętność asertywności. Okoliczności satysfakcjonującego funkcjonowania w relacji przyjacielskiej powinny być podbudowane umiejętnością realizowania 
działań zgodnych z własnym interesem przy jednoczesnej zdolności nienaruszania praw drugiej strony relacji.

Asertywność jest jednak umiejętnością bardzo trudną do realizacji; zależność między tą umiejętnością i relacją przyjacielską nie musi być prostoliniowa. Zbytnie akcentowanie przez partnera relacji jego uprawnień, zwłaszcza w początkowym stadium jej rozwoju, może doprowadzić wręcz do ograniczenia lub zaniechania relacji przyjacielskiej. Również Argyle (1999) podkreśla, że asertywność jest istotna, ale tylko wówczas, gdy jednostka dysponuje również odpowiednią ilością ciepła interpersonalnego i potrafi umiejętnie dawkować jedno i drugie. $Z$ doświadczeń terapeutycznych Yalome’a (2008) wynika tymczasem, że ludzie chcą się przyjaźnić, jednak rozważają cenę, jaką za relację muszą zapłacić, zwłaszcza gdy ceną są oni sami i niemożliwość realizowania ważnych dla nich potrzeb. Mogą co prawda poświęcić osobiste cele na potrzeby doraźnych wydarzeń w związku, jednak w dłuższej perspektywie ważnym kryterium oceny wartości danej relacji przyjacielskiej jest również poczucie satysfakcji z realizacji celów osobistych i spełnianie reguły wzajemności. Oleś (1998) podkreśla, że sama umiejętność zachowania asertywnego, bez znajomości reguł społecznego funkcjonowania, może wręcz udaremnić nawiązywanie trwałych związków interpersonalnych. Realizacja wymogu społecznej akceptacji zachowania asertywnego wydaje się dodatkowym warunkiem budowania wartościowych i trwałych relacji interpersonalnych.

$Z$ dotychczasowych ustaleń teoretycznych i empirycznych wynika, że kompetencje społeczne są istotnym czynnikiem relacji interpersonalnych, $\mathrm{w}$ tym relacji przyjacielskich. Potwierdzenie empiryczne tego przekonania można odnaleźć w badaniach Buhrmestera, Furmana, Wittenberga i Reisa (1988). Wskazują oni, że osoby z dobrze rozwiniętymi umiejętnościami społecznymi trafniej wyrażają uczucia i lepiej radzą sobie ze zrozumieniem stanu uczuć swoich przyjaciół, co związane jest również z częstszym przejmowaniem perspektywy drugiej strony relacji przyjacielskiej.

W wielu pracach podkreśla się również, że kompetencje społeczne są dodatnio skorelowane z poczuciem dobrostanu, którego ważnym wymiarem jest funkcjonowanie w relacjach przyjacielskich (Aikawa, Fujita, Tanaka, 2007; Riggio, Watring, Throckmorton, 1993; Segrin, 2000).

Inne studia empiryczne wykazały, że studenci, którzy mają rozwinięte kompetencje społeczne, mają również szerokie sieci interakcji społecznych i aktywnie w nich funkcjonują (Zsolnai, 2002).

Z kolei badania Weisz i Wood (2005) wskazują, że dorośli, którzy nie mają rozwiniętych umiejętności kooperacji czy wzajemnej wymiany zasobów, mogą być alienowani przez swoje grupy przyjacielskie.

Zależność między kompetencjami społecznymi a jakością relacji przyjaźni nie jest wszak jednostronna, w tym sensie, że należy tu oczekiwać istnienia swoistego sprzężenia zwrotnego. Zakłada się bowiem, że aktywność własna 
jednostki i jej uczestnictwo w relacjach interpersonalnych rozwijają kompetencje społeczne (Chrost, 2012, Martowska, 2012).

$\mathrm{Z}$ jednej strony wskazuje się na fakt, że funkcjonowanie społeczne wymaga pewnych zasobów i potencjału, które pozwalają na budowanie długoterminowych efektywnych sytuacji społecznych, z drugiej strony warunkiem tych relacji jest nieustanny trening społeczny. Trening daje jednostce możliwość rozwijania umiejętności nawiązywania i utrzymywania społecznych relacji. Przez różnego rodzaju wspólne aktywności z przyjacielem, działanie pod presją czasu i przy braku zasobów, przez pomaganie innym i mierzenie się ze sprawami życia codziennego jednostka wchodzi w skomplikowany świat współżycia i działania społecznego, rozwija swoje umiejętności społeczne i uzyskuje w przyszłości umiejętność budowania jeszcze bardziej satysfakcjonujących relacji interpersonalnych. Kompetencje społeczne ulegają rozwojowi, ponieważ w tych naturalnych warunkach jednostka ma dostęp do informacji zwrotnej, dzięki której może nieprzerwanie analizować przebieg interakcji. Informacja zwrotna, w następstwie jej pojawienia się, wymaga często zmodyfikowania przyjętych strategii, przetestowania nowych. W końcu też ważne jest utrzymywanie określonego poziomu refleksyjności, który pozwala na przyjmowanie przez podmiot informacji zwrotnych, pomimo osiągnięcia określonego poziomu umiejętności (Argyle, 1991, 1999).

Powyższe przypuszczenia potwierdzają niektóre badania naukowe. Hartup i Abecassis (2002) stwierdzili np., że przyjaźń pełni funkcję rozwojową dla kompetencji. Wiele umiejętności społecznych (np. radzenie sobie w sytuacjach konfliktowych) rozwija się przez interakcję w bliskich relacjach interpersonalnych. Badania Mikami i Hinshawa (2003) pokazały, że osoby mające niewielkie grupy przyjaciól, określane mianem friendless, trudniej sobie radzą z przewidywaniem konsekwencji własnych zachowań.

Podsumowując, należy wskazać, że klarowny model zależności między kompetencjami społecznymi a treningiem społecznym przedstawiły Matczak i Knopp (2013). Ich zdaniem kompetencje społeczne rozwijają się w toku funkcjonowania i działania jednostki. Cały obszar tej aktywności, to, o czym wspominano powyżej, stanowi swoisty trening. Aktywność w przestrzeni społecznej charakteryzująca się wysoką intensywnością ułatwia nabywanie kompetencji społecznych. Co istotne z punktu widzenia niniejszej pracy, nie tylko aktywność społeczna wpływa na kompetencje społeczne, lecz także i one wyznaczają pole charakterystycznego potencjału w zakresie funkcjonowania społecznego, w tym również w relacjach interpersonalnych. Autorki modelu piszą wprost o współdeterminowaniu przez kompetencje społeczne powodzenia w funkcjonowaniu społecznym, wyboru rodzaju tej aktywności i stopnia ich intensywności. 


\section{Pytanie badawcze i hipotezy badawcze}

Powyżej przedstawiono obecne w literaturze psychologicznej teorie, koncepcje oraz kierunki poszukiwań współczesnych badaczy istotne dla rozważań nad związkami kompetencji społecznych z jakością relacji przyjacielskich. Omówiony stan refleksji naukowej odnoszącej się do zagadnień kształtowania się relacji przyjacielskich z uwagi na kompetencje społeczne wskazuje, iż brak jest badań naukowych w polskich warunkach, których wyniki mogłyby potencjalnie wskazywać na istnienie związków między kompetencjami społecznymi a jakością relacji przyjacielskich, dlatego podjęto badania empiryczne. Ich kierunek wyznaczyło następujące pytanie badawcze: Czy istnieje związek między kompetencjami społecznymi przyjaciół a jakością ich relacji przyjacielskiej?

W kontekście pytania badawczego postawiono następujące hipotezy:

H1: Istnieje dodatni związek między kompetencjami społecznymi przyjaciół a jakością ich relacji przyjacielskiej.

W szczególności oznacza to, iż:

H2: Przyjaciele o wyższych kompetencjach warunkujących efektywność zachowań w sytuacjach intymnych mają wyższą jakość relacji przyjacielskich.

H3: Przyjaciele o wyższych kompetencjach warunkujących efektywność zachowań w sytuacjach wymagających asertywności mają wyższą jakość relacji przyjacielskich.

\section{METODA}

\section{Zmienne w badaniach empirycznych}

W prowadzonych badaniach empirycznych zmienną wyjaśnianą jest jakość relacji przyjacielskiej. Zmienna ta jest definiowana zgodnie z przyjętą w części teoretycznej koncepcją Arunkumara i Dharmangadana (2001). Wielowymiarową zmienną relacji przyjacielskiej stanowią również cztery komponenty. Poniżej została przedstawiona lista tych wymiarów, będących w badaniach własnych dodatkowymi zmiennymi szczegółowymi, wyczerpująco formułującymi modalność zmiennej jakość relacji przyjacielskiej. Rozważa się zatem: akceptację $\mathrm{w}$ relacji, wzajemne wsparcie w relacji, intymność w relacji, zestrojenie w relacji.

Zmienna wyjaśniająca, kompetencje społeczne, jest rozumiana zgodnie $\mathrm{z}$ definicją Matczak (2007). A zatem poza zmienną kompetencje społeczne, definiowaną jako ogólny poziom umiejętności społecznych, rozważa się również dwie, istotne $\mathrm{z}$ uwagi na badania własne, zmienne szczegółowe: kompetencje warunkujące efektywność zachowań w sytuacjach intymnych oraz kompetencje warunkujące efektywność zachowań w sytuacjach wymagających asertywności.

W badaniach empirycznych założono kontrolę dodatkowej zmiennej. Zmienną tą jest płeć. Decyzja ta wynika $\mathrm{z}$ faktu, iż w innych badaniach prowadzonych przez autora niniejszego artykułu (Prusiński, 2016c), a dotyczących zagadnienia równoważności relacji przyjacielskich kobiet i mężczyzn, została 
potwierdzona hipoteza o zróżnicowaniu jakości relacji przyjacielskiej ze względu na zmienną płeć. Różnice międzypłciowe wystąpiły w zakresie ogólnego poziomu relacji przyjacielskiej, jak również w zakresie poszczególnych komponent relacji przyjacielskiej. Analizy zmiennych będą zatem prowadzone oddzielnie dla kobiet i mężczyzn.

\section{Osoby badane}

Badania empiryczne zostały przeprowadzone w Polsce, na terenie 11 województw, w miastach powyżej 40 tys. mieszkańców. Przeprowadzano je od listopada 2015 r. do maja 2016 r. Wzięło w nich udział 213 osób między 17. a 38. rokiem życia. W próbie badawczej znalazły się 102 kobiety i 111 mężczyzn, co stanowi odpowiednio 47,9\% i 52,1\% całej grupy poddanej badaniu. Średnia arytmetyczna wieku wyniosła 23,37, odchylenie standardowe zaś - 3,38.

Niewielką reprezentację uzyskały osoby między 31. a 38. rokiem życia, których udział w całej próbie badawczej wyniósł 4,2\%, oraz osoby między 17. a 18. rokiem życia, których udział w całej próbie badawczej wyniósł 2,3\%. Badani w przedziale wiekowym 19-30 lat stanowili 93,5\% całej próby badawczej. Próbę stanowiły osoby młode, ale dorosłe, zatem populację, dla której można dokonywać oszacowań wyników, stanowią młodzi dorośli.

\section{Narzędzia badawcze}

Zmienna wyjaśniana jakość relacji przyjacielskiej z uwzględnieniem jej modalności była mierzona za pomocą narzędzia badawczego, jakim jest Kwestionariusz intensywności relacji przyjacielskiej (Friendship Intensity Measurement Scale; FIMS). Narzędzie stworzone przez Arunkumara i Dharmangadana (2001) składa się z 40 pozycji ${ }^{2}$. Pozycje kwestionariusza operacjonalizują cztery wymienione wcześniej komponenty relacji przyjacielskiej. W nawiasach przy poszczególnych skalach podano ich skróty, które będą wykorzystywane dla wygody prezentowania niektórych późniejszych wyników badań. Skale te to: akceptacja w relacji przyjacielskiej (A), wzajemne wsparcie w relacji przyjacielskiej (W), intymność $\mathrm{w}$ relacji przyjacielskiej (I), zestrojenie w relacji przyjacielskiej $(\mathrm{Z})^{3}$.

2 Osoba badana każdorazowo ocenia stopień, w jakim zgadza się z tym, że dane stwierdzenie odnosi się do jej istniejącej i opisywanej relacji przyjacielskiej: zdecydowanie nie zgadzam się; raczej nie zgadzam się; trudno powiedzieć; raczej zgadzam się; zdecydowanie zgadzam się. Odpowiedzi punktowane są w skali 1-5, część pozycji ma odwrócony klucz. Wynikiem ogólnym kwestionariusza FIMS jest suma punktów uzyskanych za odpowiedzi na pytania we wszystkich pozycjach kwestionariusza. Minimalny wynik wynosi 40 punktów, maksymalny wynosi 200 punktów.

3 Kwestionariusz FIMS pozwala również na obliczenie wyników w czterech skalach. W skład każdej skali wchodzi 10 pozycji. Minimalny wynik na każdej skali wynosi 10 punktów, maksymalny wynosi 50 punktów. 
Kwestionariusz FIMS ma kilka form, które wyznaczają odmienne warunki badawcze. W przedstawianych badaniach empirycznych użyto dwóch form narzędzia. W formie pierwszej (kwestionariusz FIMS/PM) osoba badana była proszona o pomyślenie o kimś, kto jest jej najlepszym przyjacielem mężczyzną, i o określenie poziomu swojej zgody na stwierdzenia kwestionariusza, przy założeniu, że odnoszą się one właśnie do tej osoby i do relacji z nią. W drugiej formie (kwestionariusz FIMS/PK) poproszono o rozważanie przez osobę badaną bliskiej relacji przyjacielskiej z kobietą.

Jeśli chodzi o wartości psychometryczne narzędzia ${ }^{4}$, to dane zgromadzone z badań empirycznych umożliwiły analizę rzetelności kwestionariusza FIMS. Oszacowano rzetelność (współczynniki a Cronbacha) poszczególnych skal oraz wyniku ogólnego kwestionariusza FIMS (dla dwóch wersji kwestionariusza: relacji przyjacielskiej z mężczyzną i relacji przyjacielskiej z kobietą). Wyniki rzetelności podano $\mathrm{w}$ tabeli 1 .

Tabela 1

Współczynniki rzetelności ( $\alpha$ Cronbacha) dla skal i wyniku ogólnego kwestionariusza FIMS

\begin{tabular}{lc}
\hline \multicolumn{1}{c}{ Kwestionariusz FIMS } & $\alpha$ Cronbacha \\
\hline PM ogólny & 0,89 \\
PM A & 0,72 \\
PM W & 0,72 \\
PM I & 0,60 \\
PM Z & 0,67 \\
PK ogólny & 0,93 \\
PK A & 0,83 \\
PK W & 0,82 \\
PK I & 0,73 \\
PK Z & 0,76 \\
\hline
\end{tabular}

Adnotacja. Kwestionariusz FIMS/PM ogólny - wynik ogólny (kwestionariusz w wersji badającej relację z najlepszym przyjacielem mężczyzną) i dalej w obrębie tego kwestionariusza FIMS: PM A - skala akceptacji w relacji; PM W - skala wzajemnego wsparcia w relacji; PM I - skala intymności w relacji; PM Z - skala zestrojenia w relacji. Kwestionariusz FIMS/PK ogólny - wynik ogólny (kwestionariusz w wersji badającej relację z najlepszą przyjaciółką kobietą) i dalej w obrębie tego kwestionariusza FIMS: PK A - skala akceptacji w relacji; PK W - skala wzajemnego wsparcia w relacji; PK I - skala intymności w relacji; PK Z - skala zestrojenia w relacji.

4 Kwestionariusz FIMS jest w procesie adaptacji, po zakończonych badaniach pilotażowych na populacji polskiej. Wykorzystana w badaniach wersja narzędzia jest wersją wstępną. Jednakże wstępny proces psychometrycznej walidacji eksperymentalnej wersji narzędzia wskazuje na zadowalające oceny w zakresie trafności i rzetelności kwestionariusza. Zasadne zatem wydaje się wykorzystanie go do badań nad jakością relacji przyjacielskich. 
Jak widać, rzetelność wyniku ogólnego kwestionariusza FIMS dla dwóch warunków: relacji przyjacielskiej z mężczyzną i relacji przyjacielskiej z kobietą jest bardzo wysoka. Rzetelność poszczególnych skal jest niższa, jednak oscyluje wokół wartości umiarkowanych i akceptowanych (Aranowska, 2005).

Trafność kwestionariusza FIMS była szacowana analizą czynnikową konfirmacyjną. Leżący u podstaw zbudowanego narzędzia model teoretyczny, zakładający zmienną latentną przyjaźni i jej cztery komponenty, istniał przed procesem generowania modelu czynnikowego. Na podstawie teorii sformułowano hipotezę, że relację przyjacielską tworzą cztery wymiary: akceptacja $\mathrm{w}$ relacji, wzajemne wsparcie $\mathrm{w}$ relacji, intymność $\mathrm{w}$ relacji i zestrojenie $\mathrm{w}$ relacji. Zastosowana analiza czynnikowa konfirmacyjna miała na celu sprawdzenie, czy ustalone teoretycznie podwymiary rzeczywiście tworzą skale oraz na ile struktura czynnikowa uzyskana dla próby polskiej jest porównywalna ze strukturą oryginału, co potwierdzałoby trafność czynnikową rodzimej adaptacji kwestionariusza FIMS. Do zbudowanego modelu czynnikowego wprowadzono uzyskane w badaniach pilotażowych dane empiryczne. Tabela 2 przedstawia wskaźniki dopasowania dla dwóch wersji kwestionariusza, FIMS/ PM i FIMS/PK.

Tabela 2

Wskaźniki dobroci dopasowania dla kwestionariusza FIMS

Kwestionariusz FIMS

RMSEA

$\mathrm{CMIN} / \mathrm{df}$

GFI

$\begin{array}{llll}\text { PM ogólny } & 0,08 & 2,20 & 0,75 \\ \text { PK ogólny } & 0,08 & 2,07 & 0,78\end{array}$

Adnotacja. RMSEA - pierwiastek ze średniego kwadratu błędu aproksymacji; CMIN/df - przeciętne niedopasowanie modelu w przeliczeniu na jeden stopień swobody; GFI - wskaźnik dobroci dopasowania; kwestionariusz FIMS/PM ogólny - wynik ogólny (kwestionariusz w wersji badającej relację z najlepszym przyjacielem mężczyzną); kwestionariusz FIMS/PK ogólny - wynik ogólny (kwestionariusz w wersji badającej relację z najlepszą przyjaciółką kobietą).

Jak widać, wskaźniki świadczą o umiarkowanym i akceptowalnym dopasowaniu modelu do danych (Konarski, 2016).

Zmienna wyjaśniająca, kompetencje społeczne, była mierzona za pomocą narzędzia badawczego, jakim jest Kwestionariusz Kompetencji Społecznych ${ }^{5}$ (KKS; Matczak, 2007). W niniejszych badaniach, zgodnie ze zmiennymi zdefi-

5 Kwestionariusz KKS składa się z 90 pozycji, z czego 60 to pozycje diagnostyczne, dotyczące kompetencji społecznych. Kwestionariusz KKS pozwala na obliczenie wyniku w trzech skalach oraz wyniku ogólnego. 
niowanymi wcześniej, istotne będą dwie z trzech badanych przez kwestionariusz kompetencji społecznych. W nawiasach podano skróty skal, które będą wykorzystywane dla wygody prezentowania niektórych późniejszych wyników badań. Skale te to: kompetencje warunkujące efektywność zachowań w sytuacjach intymnych (I), kompetencje warunkujące efektywność zachowań w sytuacjach ekspozycji społecznej (ES), kompetencje warunkujące efektywność zachowań w sytuacjach wymagających asertywności (A).

Rzetelność szczegółowych skal i wyniku łącznego kwestionariusza KKS jest wysoka. Obliczenia poczynione w zakresie oceny trafności narzędzia świadczą korzystnie o trafności kwestionariusza KKS jako narzędzia do pomiaru kompetencji społecznych (Matczak, 2007).

\section{Procedura badania}

Wszyscy uczestnicy badań empirycznych wypełniali trzy kwestionariusze. Dwa pierwsze kwestionariusze, FIMS/PM i FIMS/PK, dotyczyły jakości relacji przyjacielskich. Następnie każdy badany był proszony o wypełnienie kwestionariusza KKS.

Wszystkie kwestionariusze były udostępniane w wersji papierowej. Badanie zostało przeprowadzone grupowo. Czas przeznaczony na udzielenie odpowiedzi nie był ograniczony. Każdy badany mógł pracować we własnym tempie. Przeciętnie po około 45 minutach wszystkie trzy kwestionariusze były wypełnione.

\section{WYNIKI}

\section{Analizy wstępne}

W pierwszej kolejności dokonano analizy rozkładów zmiennych w badanych populacjach. W tabeli 3 przedstawiono wartości statystyk opisowych. 
Tabela 3

Charakterystyka rozkładów zmiennych z podziałem na płeć

\begin{tabular}{|c|c|c|c|}
\hline \multirow{2}{*}{ Skala } & \multirow{2}{*}{ Płeć } & \multicolumn{2}{|c|}{ Statystyki opisowe } \\
\hline & & $M$ & $S D$ \\
\hline \multirow{2}{*}{ KKS ogólny } & $\mathrm{K}$ & 168,85 & 19,87 \\
\hline & $M$ & 176,78 & 20,79 \\
\hline \multirow{2}{*}{ KKS I } & $\mathrm{K}$ & 43,68 & 5,36 \\
\hline & M & 43,23 & 5,76 \\
\hline \multirow{2}{*}{ KKS A } & $\mathrm{K}$ & 45,33 & 6,74 \\
\hline & $M$ & 50,27 & 6,53 \\
\hline \multirow{2}{*}{ KKS E } & $\mathrm{K}$ & 49,87 & 8,49 \\
\hline & $M$ & 52,65 & 8,63 \\
\hline \multirow{2}{*}{ FIMS PM ogólny } & $\mathrm{K}$ & 154,52 & 19,54 \\
\hline & $M$ & 147,27 & 17,61 \\
\hline \multirow{2}{*}{ PM A } & $\mathrm{K}$ & 42,19 & 5,38 \\
\hline & M & 39,84 & 4,87 \\
\hline \multirow{2}{*}{ PM I } & $\mathrm{K}$ & 36,54 & 5,32 \\
\hline & M & 34,86 & 5,03 \\
\hline \multirow{2}{*}{ PM W } & $\mathrm{K}$ & 34,77 & 6,64 \\
\hline & $M$ & 32,98 & 6,11 \\
\hline \multirow{2}{*}{ PM Z } & $\mathrm{K}$ & 41,02 & 5,07 \\
\hline & $M$ & 39,59 & 4,65 \\
\hline \multirow{2}{*}{ FIMS PK ogólny } & $\mathrm{K}$ & 159,97 & 20,16 \\
\hline & M & 154,53 & 23,93 \\
\hline \multirow{2}{*}{ PK A } & $\mathrm{K}$ & 42,85 & 5,41 \\
\hline & M & 41,05 & 6,83 \\
\hline \multirow{2}{*}{ PK I } & $\mathrm{K}$ & 37,77 & 5,74 \\
\hline & $M$ & 37,65 & 5,70 \\
\hline \multirow{2}{*}{ PK W } & $\mathrm{K}$ & 37,23 & 7,06 \\
\hline & $M$ & 35,57 & 7,71 \\
\hline \multirow{2}{*}{ PK Z } & $\mathrm{K}$ & 42,12 & 4,73 \\
\hline & $M$ & 40,26 & 5,90 \\
\hline
\end{tabular}

Adnotacja. KKS ogólny - wynik ogólny w Kwestionariuszu Kompetencji Społecznych; KKS I kompetencje warunkujące efektywność zachowań w sytuacjach intymnych; KKS A - kompetencje warunkujące efektywność zachowań w sytuacjach wymagających asertywności; KKS E - kompetencje warunkujące efektywność zachowań w sytuacjach ekspozycji społecznej; kwestionariusz FIMS/PM ogólny - wynik ogólny (kwestionariusz w wersji badającej relację z najlepszym przyjacielem mężczyzną) i dalej w obrębie tego kwestionariusza FIMS: PM A skala akceptacji w relacji; PM W - skala wzajemnego wsparcia w relacji; PM I - skala intymności w relacji; PM Z - skala zestrojenia w relacji; kwestionariusz FIMS/PK ogólny - wynik ogólny (kwestionariusz w wersji badającej relację z najlepszą przyjaciółką kobietą) i dalej w obrębie tego kwestionariusza FIMS: PK A - skala akceptacji w relacji; PK W - skala wzajemnego wsparcia w relacji; PK I - skala intymności w relacji; PK Z - skala zestrojenia w relacji. 
Analiza wyników uzyskanych w badaniach empirycznych pozwoliła na weryfikację postawionych w części teoretycznej hipotez badawczych. W celu weryfikacji hipotez zastosowano współczynnik $r$-Pearsona, a tam, gdzie rozkłady zmiennych odbiegały od normalnych, zastosowano współczynnik rho-Spearmana.

\section{Relacje przyjacielskie a kompetencje społeczne}

Rozpatrywane hipotezy dotyczą związku między jakością relacji przyjacielskiej a poziomem kompetencji społecznych. Postanowiono sprawdzić kierunek i siłę związku między wynikiem ogólnym, jaki uzyskały osoby badane (zarówno w przyjaźni z mężczyzną, jak i w przyjaźni z kobietą), a wynikiem ogólnym kompetencji społecznych oraz kompetencjami warunkującymi efektywność zachowań w sytuacjach intymnych i w sytuacjach wymagających asertywności. Postanowiono również sprawdzić kierunek i siłę związku między skalami opisującymi relację przyjacielską (zarówno w przyjaźni z mężczyzną, jak i w przyjaźni z kobietą) a wynikiem ogólnym kompetencji społecznych oraz kompetencjami warunkującymi efektywność zachowań w sytuacjach intymnych i w sytuacjach wymagających asertywności.

Wprawdzie nie oczekiwano związku między kompetencjami społecznymi warunkującymi efektywność w sytuacjach ekspozycji społecznej a jakością relacji przyjacielskiej, niemniej jednak KKS daje możliwość pomiaru tych kompetencji, stąd wyniki badań uwzględniają również i ten wymiar zmiennej wyjaśniającej. Tabela 4 przedstawia uzyskane rezultaty. 
Tabela 4

Współczynniki r-Pearsona i rho-Spearmana między jakościa relacji przyjacielskiej a poziomem kompetencji społecznych

\begin{tabular}{|c|c|c|c|c|c|}
\hline \multirow{2}{*}{ Płeć } & \multirow{2}{*}{$\begin{array}{c}\text { Kwestionariusz } \\
\text { FIMS }\end{array}$} & \multicolumn{4}{|c|}{ KKS } \\
\hline & & KKS ogólny & KKS I & KKS A & KKS E \\
\hline K & \multirow{2}{*}{ PM ogólny } & 0,15 & $-0,08$ & 0,11 & 0,12 \\
\hline$M$ & & $0,28^{* *}$ & $0,22 * *$ & $0,20 *$ & $0,20^{*}$ \\
\hline K & \multirow{2}{*}{ PK ogólny } & 0,05 & 0,06 & $-0,06$ & 0,07 \\
\hline M & & $0,21^{*}$ & $0,28 * *$ & 0,15 & 0,09 \\
\hline K & \multirow{2}{*}{ PK A } & $-0,02$ & $-0,04$ & $-0,12$ & 0,07 \\
\hline$M$ & & 0,13 & $0,25^{* *}$ & 0,07 & 0,02 \\
\hline K & \multirow{2}{*}{ PK W } & 0,11 & 0,10 & 0,05 & 0,08 \\
\hline$M$ & & $0,18^{*}$ & $0,26^{*}$ & 0,14 & 0,07 \\
\hline $\mathrm{K}$ & \multirow{2}{*}{ PK I } & 0,08 & 0,09 & 0,04 & 0,06 \\
\hline$M$ & & $0,21^{*}$ & $0,27^{* *}$ & $0,20 *$ & 0,06 \\
\hline K & \multirow{2}{*}{ PK Z } & 0,03 & 0,08 & $-0,10$ & 0,04 \\
\hline M & & $0,26 * *$ & $0,26 * *$ & 0,15 & $0,21^{*}$ \\
\hline $\mathrm{K}$ & \multirow{2}{*}{ PM A } & $-0,01$ & 0,02 & $-0,02$ & $-0,01$ \\
\hline$M$ & & $0,20 *$ & 0,14 & 0,12 & 0,15 \\
\hline K & \multirow{2}{*}{ PM W } & 0,14 & 0,10 & 0,13 & 0,05 \\
\hline M & & $0,20 *$ & $0,17^{*}$ & $0,16^{*}$ & 0,15 \\
\hline K & \multirow{2}{*}{ PM I } & $0,17 *$ & 0,05 & 0,14 & 0,17 \\
\hline$M$ & & $0,28^{* *}$ & $0,29 * *$ & $0,22^{* *}$ & $0,17^{*}$ \\
\hline $\mathrm{K}$ & \multirow{2}{*}{ PM Z } & $0,19 *$ & 0,08 & 0,11 & 0,22 \\
\hline$M$ & & $0,31^{* *}$ & $0,34^{* *}$ & $0,22^{*}$ & $0,24 * *$ \\
\hline
\end{tabular}

Adnotacja. KKS ogólny - wynik ogólny w Kwestionariuszu Kompetencji Społecznych; KKS I kompetencje warunkujące efektywność zachowań w sytuacjach intymnych; KKS A - kompetencje warunkujące efektywność zachowań w sytuacjach wymagających asertywności; KKS E - kompetencje warunkujące efektywność zachowań w sytuacjach ekspozycji społecznej; kwestionariusz FIMS/PM ogólny - wynik ogólny (kwestionariusz w wersji badającej relację z najlepszym przyjacielem mężczyzną) i dalej w obrębie tego kwestionariusza FIMS: PM A skala akceptacji w relacji; PM W - skala wzajemnego wsparcia w relacji; PM I - skala intymności w relacji; PM Z - skala zestrojenia w relacji; kwestionariusz FIMS/PK ogólny - wynik ogólny (kwestionariusz w wersji badającej relację z najlepszą przyjaciółką kobietą) i dalej w obrębie tego kwestionariusza FIMS: PK A - skala akceptacji w relacji; PK W - skala wzajemnego wsparcia $\mathrm{w}$ relacji; PK I - skala intymności w relacji; PK Z - skala zestrojenia w relacji.

${ }^{\star} p<0,05$ (jednostronnie); ${ }^{* \star} p<0,01$ (jednostronnie). 
Z zaprezentowanych rezultatów wynika, że związki między zmiennymi jakości relacji przyjacielskich a kompetencjami społecznymi są niskie. Istotna statystycznie jest mniej niż połowa z nich. Związki istotne statystycznie między zmiennymi są dodatnie. Wysokim wartościom jednej zmiennej towarzyszą wysokie wartości drugiej zmiennej i odwrotnie.

U mężczyzn związki dodatnie i niskie występują między wynikiem ogólnym jakości relacji przyjacielskiej (relacji zarówno z przyjacielem mężczyzną, jak i z przyjaciółką kobietą) a wynikiem ogólnym kompetencji społecznych. Dodatkowo u mężczyzn istnieją słabe związki między wynikiem ogólnym jakości relacji przyjacielskiej (relacji zarówno z przyjacielem mężczyzną, jak i z przyjaciółką kobietą) a wynikiem w zakresie kompetencji warunkujących efektywność zachowań w sytuacjach intymnych oraz związki między wynikiem ogólnym jakości relacji przyjacielskiej z mężczyzną a wynikiem w zakresie kompetencji warunkujących efektywność zachowań w sytuacjach ekspozycji społecznej i w sytuacjach wymagających asertywności.

W przypadku kobiet nie odnotowano korelacji między zmienną jakość relacji przyjacielskich, zarówno z mężczyznami, jak i z kobietami, a zmienną kompetencje społeczne (zarówno wynik ogólny, jak i poszczególne skale). Nie odnotowano również prawie żadnych związków między zmiennymi szczegółowymi jakości relacji przyjacielskiej a skalami kompetencji społecznych.

$\mathrm{Z}$ analiz statystycznych wynika natomiast, że w przypadku mężczyzn większość skal składających się na jakość relacji przyjacielskich (relacji zarówno z mężczyzną, jak i z kobietą) koreluje dodatnio z wynikiem ogólnym kompetencji społecznych, jak również z poszczególnymi kompetencjami warunkującymi efektywność zachowań w sytuacjach społecznych, zwłaszcza w sytuacjach intymnych. Z analiz statystycznych wynika, że związki jakości relacji przyjacielskich $\mathrm{z}$ kompetencjami warunkującymi efektywność zachowań w sytuacjach ekspozycji społecznej występują sporadycznie.

Podsumowując: podstawę do weryfikacji hipotez o istnieniu dodatniego związku między jakością relacji przyjacielskiej a kompetencjami społecznymi, zarówno u kobiet jak i u mężczyzn, stanowiły ujawnione wartości współczynników korelacji $r$-Pearsona i rho-Spearmana. Tylko niektóre z tych wartości okazały się istotne statystycznie. W przypadku otrzymanych wartości współczynników ich dodatni znak wskazuje na zależności o charakterze wprost proporcjonalnym. Tym samym hipotezy zostały potwierdzone. Hipotezy potwierdziły wartości współczynników ujawnione w grupie mężczyzn.

W badaniach założono, że zmienną wyjaśnianą jest jakość relacji przyjacielskich, a zmienną wyjaśniającą - kompetencje społeczne. Dodatkowo w celu ustalenia, w jakim stopniu zmienna kompetencje społeczne ma udział w wariancji wyników zmiennej jakość relacji przyjacielskiej, przeprowadzono analizę regresji.

Na podstawie współczynnika skorygowanego $R$-kwadrat widać, że w przypadku kobiet zmienna kompetencje społeczne wyjaśnia 3,8\% wariancji zmiennej 
jakość relacji przyjacielskiej (z przyjacielem mężczyzną). W przypadku relacji z przyjaciółką kobietą zaproponowany model okazał się nieistotny statystycznie.

W przypadku badanych mężczyzn zmienna kompetencje społeczne (wynik ogólny) wyjaśnia 8\% wariancji zmiennej jakość relacji przyjacielskiej z przyjacielem mężczyzną i 4,7\% wariancji zmiennej jakość relacji przyjacielskiej z przyjaciółką kobietą.

\section{DYSKUSJA}

Jeśli przez sytuacje społeczne rozumieć również dwuosobowe relacje przyjacielskie, to wydaje się, że efektywność radzenia sobie w tych sytuacjach nie jest związana z kompetencjami społecznymi tak silnie, jak można było oczekiwać na podstawie przedstawionych wcześniej analiz teoretycznych i badań empirycznych.

Umiejętności złożone, zwłaszcza te warunkujące skuteczność radzenia sobie i osiągania celów w sytuacjach intymnych czy też wymagających asertywności, tylko $\mathrm{w}$ niewielkim stopniu (graniczącym $\mathrm{z}$ umiarkowanym) warunkują jakość przyjaźni. Siła tych związków jest słaba, należy natomiast podkreślić, że generalnie $\mathrm{w}$ badaniach empirycznych prowadzonych $\mathrm{w}$ tej przestrzeni nie otrzymuje się wysokich wartości korelacji. Wartości korelacji uzyskane w obecnych badaniach są zbliżone wielkością do wartości odnotowanych w badaniach prowadzonych wcześniej.

Związki jakości relacji przyjacielskich i kompetencji społecznych zostały ujawnione przede wszystkim u mężczyzn. U kobiet praktycznie nie wystąpiły. Uzyskane współczynniki skorygowanego $R$-kwadrat $\mathrm{w}$ analizie regresji potwierdziły ten fakt.

W przypadku mężczyzn odmienna natura relacji przyjacielskiej z mężczyzną i kobietą miała umiarkowane znaczenie. Kompetencje społeczne umożliwiają sprawne i efektywne funkcjonowanie zarówno w przyjaźni męsko-męskiej, jak i przyjaźni męsko-damskiej, choć w przypadku przyjaźni męsko-męskiej odnotowano, że z jej jakością związane są wszystkie kompetencje szczegółowe. Przypuszczalnie sytuacja relacji przyjacielskiej męsko-męskiej wymaga przyjęcia takich ról społecznych i towarzyszących im zachowań, że adekwatność tego doboru wspomagają kompetencje dotyczące sytuacji intymnych, wymagających asertywności i ekspozycji społecznej. Być może u mężczyzn skomplikowana umiejętność uczestniczenia $\mathrm{w}$ różnego rodzaju układach interakcji z jednostkami zwłaszcza tej samej płci wymaga kompetencji społecznych.

Uzyskane wyniki badań wskazują przypuszczalnie również na fakt, że w przypadku relacji przyjacielskich nie wystarczy jedna umiejętność ogólna, niemająca specyficznego charakteru. Specyfika relacji przyjacielskich wymaga czasami kilku różnych umiejętności. Potwierdza to w pewnej mierze założenia teoretyczne koncepcji Matczak (2007) i Argyle’a (1999), którzy mocno 
podkreślają, że różne typy relacji interpersonalnych wymagają różnych umiejętności społecznych. Przyjaźń wydaje się relacją na tyle skomplikowaną, że wymaga większości kompetencji społecznych, o których piszą wspomniani badacze.

Na uwagę zasługują u mężczyzn zwłaszcza powiązania przyjaźni z kompetencjami warunkującymi efektywność w sytuacjach intymnych. Udział tego rodzaju kompetencji w realizowaniu przyjaźni jest ewidentny. Dotyczy to zarówno jakości relacji przyjacielskiej (wynik ogólny), jak i poszczególnych jej wymiarów: akceptacji, wsparcia, intymności i zestrojenia. Budowanie interpersonalnej syntonii przez komunikowanie szerokiej akceptacji dla działań i postaw drugiego człowieka, wspieranie go w sytuacji przeżywanych przez niego problemów, kryzysów oraz osobistych zmartwień, czy nawet przez bycie spontanicznym i autentycznym, wymaga od jednostki funkcjonowania w nieustannym emocjonalnym zaangażowaniu, bliskości i przywiązaniu. Z przedstawionych badań empirycznych jednoznacznie wynika, że w takich okolicznościach życiowych jednostka radzi sobie skuteczniej i częściej osiąga zakładane cele, jeśli korzysta $\mathrm{z}$ rozwiniętych kompetencji warunkujących efektywność działania w tak intymnej przestrzeni. Wspomniane kompetencje zdają się zatem odgrywać może niekoniecznie kluczową, lecz na pewno ważną rolę.

Podkreślić też należy, że w wypadku przyjaźni męsko-męskiej, dla utrzymania jej wysokiej jakości istotne wydają się również kompetencje warunkujące efektywność w sytuacjach wymagających asertywności. Dotychczasowe badania Unger i Crawford (1992) oraz Dwyer (2005) wskazują na to, że przyjaźń męsko-męska to przyjaźń zwłaszcza wspólnych aktywności, ale to także relacja oparta często na współzawodnictwie i porównywaniu się partnerów. Przyjaźnie męsko-męskie wypełnione są nierzadko różnego rodzaju konfliktami i sporami. Jednostki muszą się mierzyć niejednokrotnie z niezrozumiałymi oczekiwaniami drugiej strony, a przy tym dbać o realizowanie własnych potrzeb. Czasami są to relacje charakteryzujące się pewną szorstkością partnerów wobec siebie. $\mathrm{Z}$ badań prezentowanych $\mathrm{w}$ tym artykule wynika, że osiągnięcie wyższego poziomu harmonii w tak skomplikowanej częstokroć relacji czy też efektywniejsze wspieranie i bycie rzecznikiem dbającym o interesy przyjaciela jest uzależnione od posiadania kompetencji warunkujących efektywność zachowań w tym obszarze. Należy przypuszczać, że w sytuacji budowania i utrzymywania relacji przyjacielskiej istotna wydaje się również umiejętność asertywności.

Ustalone związki wydają się dodatkowym potwierdzeniem zależności opisywanych we wcześniejszych badaniach empirycznych i pracach teoretycznych. Jak już wspomniano, w badaniach Weisz i Wood (2005) wskazywano, że osoby $\mathrm{z}$ dobrze rozwiniętymi umiejętnościami społecznymi mają rozbudowane sieci przyjacielskie i nie są zagrożone alienacją społeczną. Z kolei, jak wskazują Betts i Stiller (2014), już w okresie późnego dzieciństwa umiejętnie realizowane zachowania społeczne poszerzają sieć relacji przyjacielskich. Taki związek odkryto 
u chłopców. Ikporukpo (2015) podkreśla, że wraz ze wzrostem kompetencji społecznych wśród nastolatków, zarówno dziewcząt, jak i chłopców, zwiększa się ich umiejętność budowania satysfakcjonujących relacji przyjacielskich. Gdy adolescenci mają właściwie rozwinięte kompetencje społeczne, ich przyjacielskie relacje są źródłem dobrego samopoczucia. Rutherford, Quinn i Mathur (2004) wskazują, że kompetencje społeczne pozwalają jednostkom utrzymać pozytywne relacje społeczne i uzyskiwać akceptację grup rówieśniczych, do których przynależą. Zespół Durlaka (2011) wykazał tymczasem, że rozwinięte kompetencje społeczne wspierają jednostki w podejmowaniu przez nie odpowiedzialnych decyzji dotyczących ich przyjaźni.

Bardzo charakterystycznym faktem, ujawnionym w kontekście analiz otrzymanych wyników, jest praktycznie brak powiązań między analizowanymi kompetencjami społecznymi a jakością relacji przyjacielskich w grupie kobiet. Potwierdza to również wynik przedstawionej dodatkowo analizy regresji. Pojawia się zatem pytanie, dlaczego takie związki nie zachodzą.

Dosyć łatwo o przedstawienie niejako narzucającego się od razu stanowiska, że istnieje szereg innych umiejętności i kompetencji społecznych, które wpływają na zdolność jednostki do radzenia sobie z wymaganiami i naciskami sytuacji społecznej, w tym przypadku - relacji przyjacielskiej. Być może rozpatrywane w tych badaniach kompetencje społeczne w przypadku kobiet mają marginalne znaczenie? Dlaczego jednak nie ma to przełożenia na grupę mężczyzn, u których związki jakości przyjaźni i kompetencji społecznych zostały ujawnione? Co ważne, w badaniach rozpatrywano kluczowe, zdaniem wielu badaczy, kompetencje społeczne (Argyle, 1999; Martowska, 2012; Matczak, 2008). Ich wpływ na jakość relacji interpersonalnych zdaje się potwierdzony.

W innych badaniach (Prusiński, 2016b) dotyczących kobiet ujawniono związki inteligencji emocjonalnej i jej poszczególnych komponentów z jakością relacji przyjacielskiej. Choć z badań tych wynika, że funkcjonowaniu w przyjaźni nigdzie nie towarzyszył cały aparat zdolności emocjonalnych, to jednak ich udział był niekwestionowany. Zgodnie z prezentowanym w tej pracy modelem, zdolności określają sprawność procesów poznawczych umożliwiających człowiekowi nabywanie skutecznych sposobów funkcjonowania, a kompetencje są już opanowanymi konkretnymi umiejętnościami radzenia sobie w różnych sytuacjach (Matczak, Knopp, 2013). Jak zatem wyjaśnić bieżący wynik?

Taki rezultat badań może nasuwać przypuszczenie o ważnej roli innych, poza kompetencjami, czynników budowania satysfakcjonujących relacji przyjacielskich. Myślę tu zwłaszcza o czynnikach temperamentalno-osobowościowych czy wspomnianej wyżej inteligencji emocjonalnej. Być może w przypadku kobiet wystarczą dobrze rozwinięte zdolności emocjonalne, niepodparte żadnym treningiem społecznym i rozwiniętymi kompetencjami, by uzyskać podobny wynik jakości przyjaźni, jak u mężczyzn. Być może istnieje pewien układ cech temperamentalno-osobowościowych, który wprost skłania jednostkę do unikania 
sytuacji społecznych i treningu, co wcale nie musi być sprzeczne z tym, że osoby takie mają jedną ważną i głęboką relację przyjaźni. Być może - jeśli rozpatruje się bliską relację przyjaźni w przypadku kobiet - udział kompetencji społecznych jest nieznaczny, gdyż poza nimi w utrzymywaniu tak istotnej i niepowtarzalnej relacji udział biorą również: refleksyjność, opanowanie, poszukiwanie doznań, posiadanie wiedzy na temat zasad współżycia społecznego i umiejętność przewidywania konsekwencji społecznych podejmowanych działań.

Być może bliskie relacje przyjacielskie kobiet są na tyle trwałe i stabilne (zwróćmy uwagę na przedział wiekowy osób badanych), że uruchamianie umiejętności społecznych jest już niepotrzebne? Nie dlatego, że umiejętności te nie grają żadnej roli, ale być może dlatego, że na pewnym poziomie intensywności przyjaźni nie są już tak istotne, a kobiety nie zawsze z nich korzystają. Niektórzy teoretycy zwracają uwagę, że kompetencje społeczne odgrywają ważną rolę zwłaszcza w procesie nawiązywania relacji i w jej pierwszych okresach (Argyle, 1999; Martowska, 2012).

Podsumowując: uzyskane przez autora wyniki badań empirycznych należy dopisać do wyników wcześniejszych analiz i istniejących rozważań teoretycznych w sferze poszukiwania zależności między przyjaźnią a kompetencjami społecznymi, niemniej zachodzenie oczekiwanych związków potwierdzają one tylko w części. Dyskutowane kwestie wymagają dalszych analiz. Ze względu na korelacyjny charakter badań nie należy na ich podstawie określać kierunków ustalonych zależności, choć taka pokusa nieustannie badaczom towarzyszy. Wyniki prezentowanych poszukiwań wpisują się jednak w ogólne postrzeganie kompetencji społecznych jako cech wspierających człowieka w funkcjonowaniu społecznym.

\section{Bibliografia}

Adams, R. G., Blieszner, R., De Vries, B. (2000). Definition of friendship in the third age: Age, gender, and study location effects. Journal of Aging Studies, 14, 117-133.

Adelman, M., Parks, M., Albrecht, T. (2000). Natura przyjaźni i jej rozwój.

W: J. Stewart (red.), Mosty zamiast murów: o komunikowaniu się między ludźmi (s. 376-387). Warszawa: PWN.

Aikawa, A., Fujita, M., Tanaka, K. (2007). The relationship between social skills deficits and depression, loneliness, and social anxiety: Rethinking a vulnerability model of social skills deficits. The Japanese Journal of Social Psychology, 23, 95-103.

Aranowska, E. (2005). Pomiar ilościowy w psychologii. Warszawa: Scholar. Argyle, M. (1991). Psychologia stosunków międzyludzkich. Warszawa: PWN. Argyle, M (1999). Psychologia stosunków międzyludzkich. Warszawa: PWN. 
Arunkumar, T. S., Dharmangadan, B. (2001). The FIMS. Friendship Intensity Measurement Scale. Psychological Studies, 46, 58-62.

Betts, L. R., Stiller, J. (2014). Centrality in children's best friend networks: The role of social behavior. British Journal of Developmental Psychology, 32, 34-49.

Buhrmester, D., Furman, W., Wittenberg, M., Reis, H. (1988). Five domains of interpersonal competence in peer relationships. Journal of Personality and Social Psychology, 55, 991-1008.

Chrost, M. (2012). Kompetencje emocjonalne i społeczne młodzieży. Kraków: WAM.

Davis, K. E. (1985). Near and dear: Friendship and love compared. Psychology Today, 19, 22-30.

Durlak, J. A., Weissberg R. P., Schellinger, K. B., Dymnicki, A. B., Taylor, R. D. (2011). The impact of Enhancing Students' Social and Emotional Learning: A meta-analysis of school based universal interventions. Child Development, $82,474-501$.

Dwyer, D. (2005). Bliskie relacje interpersonalne. Gdańsk: GWP.

Hartup, W. W., Abacassis, M. (2002). Friends and enemies. W: P. K. Smith, C. H. Hart. (red.), Handbook of childhood social development (s. 286-306). Maiden: Blackwell.

Ikporukpo, A. B. (2015). Enhancing friendship-making ability of peer rejected adolescents through social skills training. Ife PsychologIA, 23, 157-167.

Konarski, R. (2016). Modele równań strukturalnych. Warszawa: PWN.

Marody, M., Giza-Poleszczuk, A. (2004). Przemiany więzi społecznych. Warszawa: Scholar.

Martowska, K. (2012). Psychologiczne uwarunkowania kompetencji społecznych. Warszawa: Liberi Libri.

Matczak, A. (2001). Kwestionariusz Kompetencji Społecznych KKS. Podręcznik. Warszawa: Pracownia Testów Psychologicznych PTP.

Matczak, A. (2007). Kwestionariusz Kompetencji Społecznych KKS. Warszawa: Pracownia Testów Psychologicznych PTP.

Matczak, A. (2008). Uwarunkowania kompetencji społecznych. Warszawa: Wykład nieopublikowany UKSW.

Matczak, A., Knopp, A. K. (2013). Znaczenie inteligencji emocjonalnej w funkcjonowaniu człowieka. Warszawa: Liberi Libri.

Maxim, L. A., Nowicki, S. J. (2003). Developmental associations between nonverbal ability and social competence. Facta Universitatis, 2, 745-758.

McAndrew, F., Rybak, A. (2006). How do we decide whom our friends are? Defining levels of friendship in Poland and the United States. The Journal of Social Psychology, 146, 147-163.

Mika, S. (1987). Psychologia społeczna. Warszawa: PWN.

Mikami, A. Y., Hinshaw, S. P. (2003). Buffers of peer rejection among girls with and without ADHD: The role of popularity with adults and 
goal-directed solitary play. Journal of Abnormal Child Psychology, 3, 381-397. DOI:10.1023/A:1023839517978

Niebrzydowski, L., Płaszczyński, E. (1989). Przyjaźń i otwartość w stosunkach międzyludzkich. Studium psychologiczne. Warszawa: PWN.

Oleś, M. (1998). Asertywność u dzieci i młodzieży. Roczniki Psychologiczne, 1, 73-95.

Pahl, R. (2008). Przyjaźń - społeczne spoiwo współczesnego społeczeństwa? W:

P. Sztompka, M. Bogunia-Borowska (red.), Socjologia codzienności (s. 160180). Kraków: Znak.

Prężyna, W. (1996). Obraz siebie i partnera a wzajemna atrakcyjność w diadzie mieszanej. Roczniki Filozoficzne, 44(4), 75-133.

Prusiński, T. (2016a). Intensywne relacje interpersonalne w rzeczywistości kryzysu. Czasopismo Psychologiczne, 22(2), 317-321.

Prusiński, T. (2016b). Z badań nad przyjaźnią. Inteligencja emocjonalna a jakość bliskich relacji przyjacielskich. Psychologia Wychowawcza, 52(10), 109-124.

Prusiński, T. (2016c). Anatomia przyjaźni. Zagadnienie równoważności relacji przyjacielskich kobiet i mężczyzn. Annales Universitatis Paedagogicae Cracoviensis. Studia Psychologica, 9, 209-225.

Riggio, R., Watring, K., Throckmorton, B. (1993). Social skills, social support, and psychosocial adjustment. Personality and Individual Differences, 15, 275-280.

Rutherford, R. B., Quinn, M. M., Mathur, S. R. (2004). Handbook of Research in Emotional and Behavioral Disorders. Nowy Jork: Guilford Publications.

Ryff, C. D., Singer, B. (2001). Emotion, Social Relationships, and Health. Oxford University Press.

Segrin, C. (2000). Social skills deficits associated with depression. Clinical Psychology Review, 20, 379-403.

Spitzberg, R. H., Cupach, W. R. (1989). Handbook of interpersonal competence research. Nowy Jork: Springer-Verlag.

Szarota, P. (2014). Przyjaźń pod mikroskopem. Problemy metodologiczne w badaniach nad funkcjonowaniem relacji przyjacielskich. Psychologia Społeczna, $28,28-26$.

Szarota, P., Cantarero, K., Matsumoto, D. (2015). Emotional frankness and friendship in polish culture. Polish Psychological Bulletin, 46(2), 181-185.

Szczepańska, M., Gaweł-Luty, E. (2009). Przyjaźń jako wartość w relacjach dzieci i młodzieży. Kraków: Oficyna Wydawnicza Impuls.

Unger, R. K., Crawford, M. E. (1992). Women and gender: A feminist psychology. Nowy Jork: McGraw-Hill.

Weisz, C., Wood, L. F. (2005). Social identity support and friendship outcomes: A longitudinal study predicting who will be friends and best friends 4 years later. Journal of Social and Personal Relationship, 22, 416-432. 
Wojciszke, B., Pieńkowski, R. (1985). Q-sort Funkcjonowania Społecznego prezentacja narzędzia i przykłady jego zastosowań. Przeglad Psychologiczny, $28,527-545$.

Yalom, I. (2008). Psychoterapia egzystencjalna. Warszawa: Instytut Psychologii Zdrowia PTP.

Zsolnai, A. (2002). Relationship between social competence, learning motivation and school achievement. Educational Psychology, 22, 317-329. 